\title{
The thin essence of public diplomacy concept in communication and PR in Finland
}

\section{Elina Melgin}

\author{
Viittausohje: \\ Melgin, E. (2022). The thin essence of public diplomacy concept in communication and PR in Finland \\ [Julkisuusdiplomatian ohut olemus suomalaisessa viestintäkäsitteistössä]. Prologi - Viestinnän ja \\ vuorovaikutuksen tieteellinen aikakauslehti, 17(1), 62-69. https://doi.org/10.33352/prlg.111869 \\ To cite this article: \\ Melgin, E. (2022). The thin essence of public diplomacy concept in communication and PR in Finland. \\ Prologi - Journal of Communication and Social Interaction, 17(1), 62-69. \\ https://doi.org/10.33352/prlg.111869
}

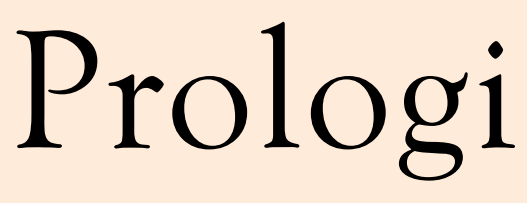

\section{- Viestinnän ja vuorovaikutuksen tieteellinen aikakauslehti journal.fi/prologi/}

ruotsiksi: Prologi - Tidskrift för Kommunikation och Social Interaktion englanniksi: Prologi - Journal of Communication and Social Interaction Julkaisija: Prologos ry.

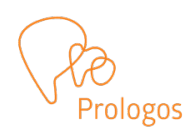

Avoin julkaisu / Open Access

ISSN 2342-3684 / verkko

ISSN 1795-7613 / painettu versio 


\title{
Näkökulma-artikkeli
}

\section{The thin essence of public diplomacy concept in communication and PR in Finland}

\author{
Elina Melgin \\ FT, Dosentti \\ Toimitusjohtaja, ProCom \\ elina.melgin@utu.fi
}

vastaanotettu 25.10.2021 / hyväksytty 26.10.2021 / julkaistu 21.1.2022

KEYWORDS: Communication, diplomacy, new public diplomacy, organization, PR, public diplomacy

Globalization and advances in technology have made it possible for almost everybody -and particularly for communication professionalsto network internationally in person or on social media platforms, to negotiate and promote trade, to form cultural and other relations, and to play a part in image building of their nation. If decades ago, official diplomatic relations were handled mainly by a small and privileged group of state officials, associations and companies of today - in the era of social media- are just as able to engage in international relations and have influence as those traditionally seen as such actors. Interaction of influence between states and multinational organizations takes place but what kind of vocabulary do we use about the diplomacy related work in the field of communication and PR in Finland?

The basic skills of communication professionals include negotiation, engagement, building trust, listening, and working in networks, both within an organization and beyond it (Tench et al., 2017; Zerfass \& Volk, 2017). The same characteristics are required of modern diplomats (see e.g., Fletcher 2016; Fréshette, 2013). If we think about the concept of diplomacy, it has two definitions. The first is the traditional definition, whereby diplomacy concerns the management of relationships between states, while the second definition describes diplomacy as the skill of dealing with people without 
threatening anybody. It is not easy to point out whether diplomacy is addressed as a process or as a skill when we think about the current public arena. Particularly public diplomacy is often understood as communication, PR and building a favorable impression, reputation and a country brand. (Melgin \& Nieminen, 2018).

This article compiles some diplomacy related concepts and practices and considers the importance of communication in modern contemporary public diplomacy. I ponder why communication professionals in Finland speak so little about public diplomacy within their own organizations or in the society in general. I propose that public diplomacy is practiced, but organizations do not yet identify its full meaning perhaps because of the absence of internationally recognized concepts.

\section{Traditional and new public diplomacy}

A variety of diplomatic concepts are used in public relations (PR) in different countries (see e.g., Ingenhoff \& Marschlicht, 2019; L'Etang, 2009, Löffelholz et al., 2015; Macnamara, 2011;) in order to clarify content related to international relations (IR), corporate diplomacy (CD), organizational diplomacy (OD), public diplomacy (PD), and new public diplomacy (NPD). The term new public diplomacy was invented already twenty years ago, and it tries to clarify the growth of the role of companies and organizations in solving multinational problems in the era that is called hybrid media landscape (see e.g., Chadwick, 2013). Despite the range of literature published (Vanc \& Fitzpatrick, 2015), PR practitioners in general do not see the full potential of new public diplomacy in their profession. In Finland, the term new public diplomacy (uusi julkisuusdiplomatia) is very rarely used in daily business. In the Ministry of Foreign Affairs in Finland, public diplomacy is used in global context but inside Finland the concept used is "country image work" (maakuvatyö). (Melgin \& Nieminen, 2019). "Maakuvatyö" does not describe the whole agenda of public diplomacy. Same concept-related problem concerns the term PR (suhdetoiminta). The commonly used term in Finland is communication (viestintä). PR is not used in Finnish daily business. However, PR has been used as a key concept in communication research. This article describes the evolution of public diplomacy and provokes a question: How it is possible to join international research discussion if the key concepts are not actively used in Finnish communication and PR field?

\section{The heaven of diplomacy related concepts}

The international academic discussion has pondered the question of how diplomacy relates to communication and PR (e.g., Dyke \& Verčič, 2009; Ingenhoff \& Buhmann, 2017, Pamment et al., 2017; Signitzer \& Coombs, 1992). It has, thus far, sought conceptual similarities and differences between PR and public diplomacy.

The comparison has sometimes been perceived as the "window dressing of PR" (Macnamara, 2011, p, 313). Some researchers believe that there is a need for a transdisciplinary approach to diplomacy and PR research (e.g., Gilboa, 2008; Macnamara, 2011). A lack of examples of the real power issues has been identified ( $\mathrm{L}^{\prime} \mathrm{E}$ tang, 2009; Melissen, 2013) as well as a lack of empirical cases (with exceptions such as Han \& Yang, 2017; Molleda \& Kochhar, 2019;). 


\section{History in a nutshell}

Propaganda was a rather neutral diplomatic concept until the dawn of WWII, also in Finland. After the war, the meaning of propaganda was too closely associated with wartime memories to suit the needs of state diplomacy corps like the U.S. Information Agency. The concept of public diplomacy emerged as an alternative to the term propaganda in USA during 1960's. Before, the phrase 'public diplomacy' had been used in the London Times (1856) and New York Times (1871) in the context of politics; it was used during the Great War to "describe a cluster of new diplomatic practises" (Cull, 2009, p. 20). As Cull (2009), a public diplomacy historian, illustrates in describing the early use of the term, there was a need for openness in the politics and diplomacy reported in the newspapers, especially in the U.S., Germany, and Great Britain. The more targeted concept of corporate diplomacy was also in use in the U.S. by the 1960s (Molleda \& Kochhar, 2019).

Over the course of the past century, the concept of public diplomacy has metamorphosed several times. Particularly the Americans have used public diplomacy as a euphemism for propaganda. According to early definitions, public diplomacy described the U.S. efforts to reach foreign audiences with overseas information. It has been seen as a way to promote a country's image or national self-advertisement (e.g., Fields, 2015). Since the 9/11 terrorist attacks in 2001, the U.S. diplomacy and public diplomacy became dominated by themes of national security and counter-terrorism (Melissen, 2011), and the idea of new public diplomacy came to the fore (Melissen, 2013). The new public diplomacy concept has been the centre of more recent international diplomatic discourse (Heine, 2013; Taylor, 2009; Potter, 2002-2003).
Today, corporations and associations operate in the context of state-level political relations. Thanks to the 21st-century technological developments, diplomacy has become an activity engaged in by all democratic actors with the aim of promoting intercultural consensus, building and maintaining collaborative relationships, and wielding influence to realise shared goals (see e.g., Fiske de Gouveia \& Plumridge, 2005).

The whole concept of diplomacy has become vaguer in the 21 st century. It has been split into several parts. For example, people speak of digital diplomacy, "Twiplomacy", preventive diplomacy, citizen diplomacy, and city diplomacy (Adesina, 2017; Cooper et al., 2013; Melissen \& van der Pluijm, 2007;). Diplomacy has become an acceptable method to use in all types of interaction and communication that bring together different cultures and involve working in an amicable spirit with the citizens of different countries or with different civil groups within a country.

\section{Similarities and differences in traditional and new public diplomacy}

The following aspects are often found in traditional public diplomacy and new public diplomacy (Löffelholz et al., 2015; Melissen, 2013; Szondi, 2008):

- The purpose is to increase sympathy and understanding towards civic or national capital (culture, social models, etc.) and goals.

- Traditional public diplomacy and new public diplomacy can be used to build an identity and create a positive impression of a country, its relations, and its alliances. 
- Traditional and new public diplomacy can be used to promote tourism, international business, and foreign capital investment. The country, organizations, companies, and individuals all ultimately benefit from this.

- Traditional and new public diplomacy aim to reduce negative generalisations and prejudices either directly or indirectly.

- Perhaps the main difference concerns civic actors: New public diplomacy highlights the work of all civic actors:

- Non-governmental organizations also engage in new public diplomacy alongside government-controlled organizations.

- New public diplomacy no longer exclusively targets foreign countries; it may also target domestic audiences, either directly or through the media.

According to the list of similarities and differences of public diplomacy concepts, I may summarize that the "newness" of new public diplomacy refers to the change in democracies. In the so-called hybrid times, anyone can take part of international and domestic political discourse in social media platforms. Citizens of today live in the global context. According to Nelson and Izadi (2009), public diplomacy in the U.S. lacks ethics and genuine dialogue. Therefore, scholars use different terms, like new public diplomacy, dialogue-based-public diplomacy, multi-stakeholder diplomacy, and network-oriented public diplomacy. In addition, Melissen (2011) states: Not all nations are afraid of terror attacks the same way as the U.S. is.

\section{Diplomacy and propaganda}

The negative connotations associated with propaganda, or the actions of powerful leaders tend to colour the whole concept of diplomacy. It happens in discussion of the historical or present usage of soft power to win the hearts and minds of targeted groups, the way China does with its Panda diplomacy (Huang \& Wang, 2020), or Trump-style usage of "Twiplomacy" (Šimunjak \& Caliandro, 2019). Adding disinformation campaigns masked as diplomacy to the picture (Bjola \& Pamment, 2019; Nimmo, 2016), the whole concept of diplomacy is in danger of losing the essence of peaceful interaction between different state and non-state actors.

Interestingly, the criticism towards traditional and new public diplomacy still focuses on propaganda and one-way information distribution (see Guth, 2008). In order to overcome the historical burden and retain perspective while getting involved in supranational issues, organizations need to focus on a two-way symmetrical public diplomacy, values-based leadership, and ethical standards (Nelson \& Izadi, 2009). Melissen (2013, p. 439) sees the future of traditional and new public diplomacy in a less nationalistic way of working for common interests and global public goods, which he refers to as "global public-diplomacy consensus".

The range of research literature published on PR and public diplomacy (Vanc \& Fitzpatrick, 2015) has not yet helped PR professionals to agree upon the concepts or role of PR professionals in the changing field of public diplomacy. For example, corporate diplomacy has been defined as "the corporate activities of multinational companies, which are directed at the host country's key stakeholders and aimed at participating in decision-making processes 
on relevant socio-political issues and building relationships in order to gain corporate legitimacy" (Ingenhoff \& Marschlich, 2019, p. 358). Corporate diplomacy is well suited to being the key concept of companies, but it does not suit PR work done in a multi-actor context in any organization.

\section{PR persons and diplomatic work}

Traditional public diplomacy was used in the era of print media and traditional broadcast media, like radio and TV. The media landscape where public diplomacy is practiced has changed dramatically over the years. Major changes in the 2010s have challenged traditional public diplomacy and diplomacy in general so severely that there has even been talk of the death of the diplomatic profession (Rothkopf, 2009). However, many popular diplomats have millions of followers on social media (Adesina, 2017), and "old school" diplomats have been advised to learn to cope with digitalization (Fletcher, 2016).

Diplomacy is generally seen as a negotiation process between actors. We speak about diplomatic attitude or even "daily diplomacy" (Mustajoki, 2019). Diplomacy is a skill of ambassadors, statespersons, other influential leaders, and PR professionals (?) primarily associated with international interaction and persuasion. In the past, PR professionals were the actors of propaganda machinery, but the modern era has altered the profession (at least in the western civilizations) to embody the opposite. PR professionals have taken on the task of fact-checking in the fight against disinformation. Disinformation is one of the biggest global problems in modern society, according to the Institute of Public Relations (McCorkindale, 2019). In
Finland, the urgency of this problem has been growing (ProCom, 2017).

The basic skills of communication professionals include building trust, listening and working in networks. Some researchers describe modern communication professionals as occupying the role of ambassador, advocate, or bridge builder (Asunta, 2016; Tench et al., 2017;). The ability to act ethically is the mark of a communication professional (Asunta, 2016). The same characteristics are required of diplomats (see e.g., Fletcher 2016; Fréshette, 2013).

Recent discussions on new public diplomacy have proposed the need for more criticism and more theory to strengthen the academic legitimacy of the study in the field (Melissen, 2013; Melissen \& Wang, 2019). It seems that new public diplomacy is still struggling with reaching a status of a solid concept in modern political studies or in PR studies. Many researchers have criticised the North American dominated research on public diplomacy (e.g., Löffelholz et al., 2015; Yun, 2012). New terms have also been proposed but they mainly align with the needs of American entities that have begun to exercise foreign policy and diplomacy based on "soft power" in their international relations as a counterbalance to hard power (Nye, 2004; Snow, 2009).

\section{Is public diplomacy needed in Finland?}

New public diplomacy is as a multi-actor interaction that aims to build networks and influence political decision-making, not only for image-boosting purposes but also to solve supranational problems like climate change, build societal resilience, and strive for the common good, beyond organizations' own good. In the 
current times, new public diplomacy practices require an understanding of not only the cultures, media landscapes, and socio-economic systems of other countries but also the culture of the disinformation sphere. I believe there is a huge potential for PR people in the arena of global diplomatic work to strive for common interest and common good. For PR professionals, the challenge is to teach management and organization members to take a stronger role in public diplomacy, to link organizations' purpose to a larger context, as well as to coach organizations to understand the nature of the sphere. Furthermore, they also need to be aware of when and how their organization may become part of somebody else's (hostile) agenda (e.g., a field of industry becoming the target of a disinformation campaign), and the importance and fragility of trust.

It is obvious that the new public diplomacy practices are already at play in Finland. For example, Finnish organizations, not only state related organizations, collaborate in multinational initiatives like climate change and girls' education. But how to verbalize and make visible the work if not with internationally used and recognized concepts? I argue that if PR vocabulary in Finland overlooks the concepts of public diplomacy, it may reveal that PR work is perceived more narrowly than the globally understood PR. I also wish that the field of PR in Finland would better realize the huge potential of public diplomacy in PR.

I believe that if organizations and their PR professionals take an active role in public diplomacy and use internationally comparable concepts, they may implement change and take a stronger role in international influencing.

University scholars in PR in Finland must know public diplomacy research, but for some reason teaching in this area is left to a few. The "country image work" used by the Ministry of Foreign Affairs in Finland does not support the cause as it in reality excludes the link for political or social and global influencing, and reduces idea of public diplomacy to almost solely "country branding". Unfortunately, the wide agenda of public diplomacy remains unknown for students who are the future PR influencers in organizations acting in global diplomatic context.

The work of modern, i.e., new public diplomacy, should be done not only in multinational context but also on a domestic scale. We need public diplomacy because of work-related and other forms of immigration. Interaction within a country with individuals from different cultural backgrounds requires diplomatic skills of PR professionals in charge of stakeholder relations. Diversity and inclusion belong to PR. Both traditional and new public diplomacy aim to reduce negative generalisations and prejudices either directly or indirectly. In the end, public diplomacy work done by PR professionals relates to peace and preservation of democracy.

Special thanks to University Lecturer Laura Asunta for the encouragement to write this piece.

\section{References}

Adesina, O. S. (2017). Foreign policy in an era of digital diplomacy. Cogent Social Sciences, 3(1). https://doi.org/10.1080/23311886.2017.1297175

Asunta, L. (2016). The role, the goal and the soul of professional public relations: Developing a holistic model of PR professionalism, Jyväskylä Studies in Humanities, No. 276. Available online: https://jyx. jyu.fi/dspace/handle/123456789/48239 
Bjola, C., \& Pamment, J. (2019). Countering online propaganda and extremism. The dark side of digital diplomacy. Routledge.

Chadwick, A. (2013). The hybrid media system. Politics and power. Oxford University Press.

Cooper, A. F., Heine, J., \& Thakur, R. (Eds.) (2013), The Oxford handbook of modern diplomacy. Oxford University Press.

Cull, N.J. (2009). Public diplomacy before Gullion. The evolution of a phase. In N. Snow \& P.M. Taylor (Eds.), Routledge handbook of public diplomacy (pp. 19-23). Routledge.

Fields, M. (2015). Reinforcing Finland's attachment to the west - British and American propaganda and cultural diplomacy in Finland, 1944-1962. University of Helsinki.

Fiske de Gouveia, P. \& Plumridge, H. (2005), European infopolitik: developing EU public diplomacy strategy. London, UK: The Foreign Policy Centre. Available online: http://www.kamudiplomasisi.org/pdf/kitaplar/EUpublicdiplomacystrategy.pdf

Fletcher, T. (2017). The naked diplomat. Understanding power and politics in the digital age. William Collins.

Gilboa, E. (2008). Searching for theory of public diplomacy. The Annals of the American Academy of Political and Social Science, 616(1), 55-77.

Guth, D. W. (2008), Black, white, and shades of gray: The sixty-year debate over propaganda versus public diplomacy. Journal of Promotion Management, 14, 309-325.

Han, J., \& Yang, S-U (2017). Investigating the role of non-governmental organizations in new public diplomacy. Autonomy and collaboration between the Voluntary Agency Network of Korea (VANK) and the Korean government on national reputation. Journal of Asian Pacific Communication, 27(2), 169-212.

Heine, J. (2013). From club diplomacy to network diplomacy. In A. F. Cooper, J. Heine \& R. Thakur (Eds.). The Oxford handbook of modern diplomacy. Oxford University Press.

Huang, Z.A. \& Wang, R. (2020). Panda engagement' in China's digital public diplomacy. Asian Journal of Communication, 30, 118-140. 10.1080/01292986.2020.1725075.

Ingenhoff, D. \& Buhmann, A. (2017) Public diplomacy. Messung, entstehung und gestaltung von länderimages. Konstanz Halem Verlag.
L'Etang, J. (2009). Public diplomacy and diplomacy in a globalized world: an issue of public communication. American Behavioral Scientist, 53(4), 607-626.

Löffelholz, M., Auer, C. \& Srugies, A. (2015). Strategic dimensions of public diplomacy. In D. Holzhausen, \& A. Zerfass (Eds.), The Routledge handbook of strategic communication (pp. 439-458). Taylor \& Francis.

Macnamara, J. (2011). Corporate and organizational diplomacy: an alternative paradigm to PR. Journal of Communication Management, 16(3), 312-325.

McCorkindale, T. (2019). 2019 IPR Disinformation in society report, Institute for Public Relations. Available online: https://instituteforpr.org/ipr-disinformation-study/

Melgin, E. \& Nieminen, H. (2018) Julkisuusdiplomatia ja viestintä. In E. Melgin \& H. Nieminen (Eds.), ProComma Academic, Diplomaattinen viestintä (pp. 10-28). Libris. https://doi.org/10.31885/2018.00028

Melissen, J. (2011), Beyond the new public diplomacy. In Clingendael paper 3. Netherlands Institute of International Relations Clingendael. Available online: https://www.clingendael.org/sites/ default/files/pdfs/20111014_cdsp_paper_jmelissen. pdf

Melissen, J. (2013). Public diplomacy. In A. F. Cooper, J. Heine, \& R. Thakur (Eds.), The Oxford handbook of modern diplomacy. Oxford University Press.

Melissen, J. \& van der Pluijm, R., (2007). City diplomacy: the expanding role of cities in international politics. Netherlands Institute of International Relations Clingendael. Avalaible online: https:// www.uclg.org/sites/default/files/20070400_cdsp_ paper_pluijm.pdf

Melissen, J. \& Wang J. (2019) Introduction: Debating public diplomacy. The Hague Journal of Diplomacy, $14,1-5$.

Mustajoki, A. (2018) Arjen diplomatiaa: voiko liika kohteliaisuus olla syynä väärinymmäryksiin? In E. Melgin \& H. Nieminen (Eds.) ProComma Academic. Diplomaattinen viestintä (pp 50-63). Libris. https:// doi.org/10.31885/2018.00028

Nimmo, B. (2016). Identifying disinformation: an $\mathrm{ABC}$ approach. In Institute for European Studies Policy Brief, No. 1. Available online: http:// www.ies. be/node/3612

Nye, J. (2004). Soft Power: The Means to Success in World Politics. Public Affairs: New York. 
Pamment, J., Dolea, A., \& Ingenhoff, D. (2017). The European refugee crisis: organisational responses and communication strategies. Journal of Communication Management, 21(4), 322-325. Available online: https://doi.org/10.1108/JCOM-09-2017-0095

Potter, E. (2003). Canada and the new public diplomacy. International Journal, 63(1), 43-64.

ProCom (2017). Johtavien viestijöiden tutkimus 2017. Published online: http://procom.fi/ wp-content/uploads/2017/04/FINAL.2017_ Johtavien_viestij\%C3\%B6iden_tutkimus_ProCom_ raportti.pdf

Rothkopf, D. (2009). Do we really need ambassadors? FP News. Available online: http://foreignpolicy. com/2009/05/28/do-we-really-need-ambassadors/

Snow, N. (2009). Rethinking public diplomacy. In N. Snow \& P. Taylor (Eds.), Routledge handbook of public diplomacy (pp. 3-11). Routledge.

Signitzer, B. \& Coombs, T. (1992). Public relations and public diplomacy: conceptual divergence. Public Review, 18(2), 137-47.

Šimunjak, M. \& Caliandro, A. (2019). Twiplomacy in the age of Donald Trump: is the diplomatic code changing? The Information Society, 35(1), 13-25. DOI: $10.1080 / 01972243.2018 .1542646$

Szondi, G. (2008). Public diplomacy and nation branding: conceptual similarities and differences. In discussion paper. Netherlands Institute of International Relations Clingendael. Available online. https://www.clingendael.org/sites/default/files/ pdfs/20081022_pap_in_dip_nation_branding.pdf
Taylor, P. (2009). Public diplomacy and strategic communication. In N. Snow \& P. Taylor (Eds.) Routledge handbook of public diplomacy (pp. 12-16). Routledge.

Tench, R., Verčič, D., Zerfass, A., Moreno, A., \& Verhoeven, P. (2017). Communication excellence: How to develop, manage and lead exceptional communications. Palgrave Macmillan.

Vank, A.M. \& Fritzpatrick, K.R. (2016). Scope and status of public diplomacy research by public relations scholars, 1990-2014. Public Relations Review, 42(3), 432-440.

Yun, S-H. (2012). Relational public diplomacy. The perspective of sociological globalism. International Journal of Communication, 6(212), 2199-2219. Available online: https://ijoc.org/index.php/ijoc/ article/view/1622

Zerfass, A., Moreno, Á., Tench, R., Verčič, D., \&Verhoeven, P. (2017). European communication monitor 2017. How strategic communication deals with the challenges of visualisation, social bots and hypermodernity. Results of a survey in 50 Countries. Available at www.communicationmonitor.eu

\section{OTSIKKO JA ASIASANAT SUOMEKSI:}

\section{Julkisuusdiplomatian ohut olemus suomalaisessa viestintäkäsitteistössä}

ASIASANAT: Diplomatia, julkisuusdiplomatia, organisaatio, suhdetoiminta, uusi julkisuusdiplomatia, viestintä 